\title{
The Effect of Amine Types on Breakthrough Separation of Methane on Biogas
}

\author{
Kuni Masruroh, Rochim Bakti Cahyono, Imam Prasetyo, Teguh Ariyanto* \\ Department of Chemical Engineering, Faculty of Engineering, Universitas Gadjah Mada, Indonesia
}

\begin{abstract}
Methane $\left(\mathrm{CH}_{4}\right)$ and carbon dioxide $\left(\mathrm{CO}_{2}\right)$ are the main components of a renewable energy source of biogas. Separation of $\mathrm{CO}_{2}$ from biogas is significantly important to improve biogas performance, due to heating value in biogas depends on the concentration of methane. One of the gas separation technologies that has been widely used in chemical industries is carbon molecular sieve (CMS). This research explores the potential of CMS for biogas purification. CMS was prepared by modification of palm kernel shell-derived porous carbon using amine groups such as monoethanolamine (MEA), 2-amino-2-methyl-1-propanol (AMP), and diethanolamine (DEA). The effect of amine types on the separation parameters was studied by using a breakthrough experiment to obtain the most potential CMS materials. The methods of this research include the process of carbon oxidation using hydrogen peroxide, impregnation with an amine group, characterization of the CMS material obtained, $\mathrm{CO}_{2}$ and $\mathrm{CH}_{4}$ gas separation testing with a breakthrough system. The $\mathrm{CMS}$ was characterized by using $\mathrm{N}_{2}$ sorption analysis, fourier transform infrared spectroscopy, and scanning electron microscopy. The breakthrough experiment showed that CMS-MEA had the highest performance for separating $\mathrm{CO}_{2}$ and $\mathrm{CH}_{4}$ gases. In addition, the results also showed that loading of amine groups on carbon caused an increase in the uptake capacity of $\mathrm{CO}_{2}$, and the highest capacity was achieved by CMSMEA of $13.2 \mathrm{mg} / \mathrm{g}$.
\end{abstract}

Keywords: amine groups, biogas, breakthrough time, carbon molecular sieve, $\mathrm{CO}_{2}$ gas separation

Article History: Received: $15^{\text {th }}$ Oct 2020; Revised: $3^{\text {rd }}$ Dec 2020; Accepted: $15^{\text {th }}$ Dec 2020; Availableonline: $20^{\text {th }}$ Dec 2020

How to Cite This Article: Masruroh, K., Cahyono, R.B., Prasetyo, I., Ariyanto,T. (2021), The Effect of Amine Types on Breakthrough Separation of Methane on Biogas. Int. Journal of Renewable Energy Development, 10(2), 249-255.

https://doi.org/10.14710/ijred.2021.33514

\section{Introduction}

Renewable energy sources are used as an alternative to minimize the use and dependence of fossil fuels. Research and development of renewable energy have been widely studied. Biogas is a renewable energy source that can be an alternative solution to supply energy demand with advantages such as low environmental impact and high energy efficiency (Appels et al., 2008; Ariyanto et al., 2017; Poletti et al., 2011). Biogas has the potential as a substitute for fossil fuels in several applications, such as for heating, electricity generation, and vehicle fuel when upgraded to bio-methane (Rasi et al., 2011). Therefore, biogas can contribute to reducing greenhouse gas emissions.

The composition of biogas consists of methane $\left(\mathrm{CH}_{4}\right)$ and carbon dioxide $\left(\mathrm{CO}_{2}\right)$ and other impurities in very small amounts such as water $\left(\mathrm{H}_{2} \mathrm{O}\right)$, hydrogen $\left(\mathrm{H}_{2}\right)$, nitrogen $\left(\mathrm{N}_{2}\right)$, hydrogen sulfide $\left(\mathrm{H}_{2} \mathrm{~S}\right)$, oxygen $\left(\mathrm{O}_{2}\right)$, and ammonia $\left(\mathrm{NH}_{3}\right)$. Biogas components are divided into two categories, namely combustible and non-combustible components. The detailed composition of biogas is presented in Table 1.

Compared with natural gas which has a heating value of $36 \mathrm{MJ} / \mathrm{Nm}^{3}$, biogas containing $60 \% \mathrm{CH}_{4}$ has a lower heating value, namely $21.5 \mathrm{MJ} / \mathrm{Nm}^{3}$ (Hosseini \& Wahid, 2014). The purity of the biogas is a very important consideration because it affects the calorific value produced. The energy in biogas depends on the concentration of methane so that the biogas produced needs to be purified against other impurities.

The carbon dioxide content can limit the use of biogas as renewable energy. The high percentage of $\mathrm{CO}_{2}$ in biogas causes the calorific value of the biogas to decrease, corrodes equipment, and increases emissions (Akkarawatkhoosith et al., 2019; Ricaurte et al., 2012). Removal of $\mathrm{CO}_{2}$ content can convert the concentration of methane to a higher level, which is commonly referred to as biomethane $(>95 \%$ methane) so that the calorific value of biogas can be increased as contained in natural gas.

Table 1

Composition of biogas(Mursec et al., 2009; Surendra et al., 2014)

\begin{tabular}{lll}
\hline Component & Concentration & Category \\
& & \\
\hline Methane $\left(\mathrm{CH}_{4}\right)$ & $50-75 \%$ & Combustible \\
Carbon dioxide $\left(\mathrm{CO}_{2}\right)$ & $25-50 \%$ & Non-combustible \\
Water $\left(\mathrm{H}_{2} \mathrm{O}\right)$ & $1-5 \%$ & Non-combustible \\
Hydrogen $\left(\mathrm{H}_{2}\right)$ & $<1 \%$ & Combustible \\
Nitrogen $\left(\mathrm{N}_{2}\right)$ & $0-5 \%$ & Non-combustible \\
Hydrogen sulfide $\left(\mathrm{H}_{2} \mathrm{~S}\right)$ & $0-5000 \mathrm{ppm}$ & Combustible \\
Oxygen $\left(\mathrm{O}_{2}\right)$ & $<1 \%$ & Non-combustible \\
Ammonia $\left(\mathrm{NH}_{3}\right)$ & $0-500 \mathrm{ppm}$ & Non-combustible \\
\hline
\end{tabular}

${ }^{*}$ Corresponding author: teguh.ariyanto@ugm.ac.id 
The method that can be used to separate $\mathrm{CO}_{2}$ and $\mathrm{CH}_{4}$ in biogas is a molecular sieve. One of the effective potential molecular sieves for $\mathrm{CO}_{2}$ gas separation is the carbon molecular sieve (CMS). CMS is a porous carbon material with most of the pores scattered in micropore size, which are able to distinguish molecules based on differences in diffusion rate, size, and shape (Mohamed et al., 2010; Prasetyo et al., 2020; Silvestre-Albero et al., 2009; Wahby et al., 2012). The separation of gas mixtures at CMS is determined by several parameters such as pore structure, affinity, and interaction of gas molecules with the carbon surface (Prasetyo et al., 2017). Due to the CMS has large micropores and excellent molecular sieving properties so that CMS plays an important role in gas separation (TaeHwan et al., 2003). One of the materials that have the potential to be used as CMS is biomass from palm kernel shells because it has a high carbon (C) content of around 50\% (Rashidi \& Yusup, 2017).

Several studies related to the separation of $\mathrm{CO}_{2}$ gas using carbon molecular sieve have been studied. Palm shell was used to prepare CMS and the results showed high selectivity for the separation of $\mathrm{O}_{2} / \mathrm{N}_{2}$ and $\mathrm{CO}_{2} / \mathrm{CH}_{4}$ ( $\mathrm{Ahmad}$ et al., 2008). The working capacity and the selectivity of the separation of $\mathrm{CO}_{2}$ and $\mathrm{CH}_{4}$ using commercial carbon molecular sieve have been studied, the results show that the adsorption capacity of $\mathrm{CO}_{2}$ is greater than that of $\mathrm{CH}_{4}$ (Song et al., 2017). Separation of $\mathrm{CO}_{2} / \mathrm{CH}_{4}$ using CMS prepared from coal tar pitch which presents molecular sieving properties to separate $\mathrm{CO}_{2}$ from $\mathrm{CH}_{4}$ results comparable to the yield of commercial molecular sieves (Alcañiz-Monge et al., 2011).

The performance of porous carbon such as CMS for binary gas separation can be improved by several treatments such as oxidation, heat treatment, and chemical impregnation with acid or alkaline solutions on the carbon surface (Lee et al., 2013). In previous research, hydrogen peroxide has been applied for the oxidation of carbon molecular sieve to enhance the separation of $\mathrm{CH}_{4} / \mathrm{CO}_{2}$ mixed gas (Cho et al., 2015). Other research has been reported to identify the effect of impregnation CMS using ammonium hydroxide (Bai et al., 2013). Both kinds of research show the improvement of the breakthrough separation process of $\mathrm{CO}_{2}$ and $\mathrm{CH}_{4}$ gases. Based on this literature, the presence of chemical species on the carbon surface greatly affects the performance of carbon materials.

Research related to CMS modification on the performance of breakthrough separation is still being developed. Porous carbon impregnated with alkaline groups such as amines have the potential to capture $\mathrm{CO}_{2}$ in biogas due to the primary and secondary amines can react with $\mathrm{CO}_{2}$ to form stable compounds and can be regenerated to release adsorbed $\mathrm{CO}_{2}$ (Das \& Meikap, 2020). However, CMS is less hydrophilic than other similar porous materials (Tae-Hwan et al., 2003). In this study, a combination of several treatments was used to improve the performance of CMS. CMS was prepared by modification of palm kernel shell-derived porous carbon using two treatments including oxidation and impregnation of amine groups. The oxidation treatment using hydrogen peroxide was previous carried out during the impregnation process. Oxidation is a pre-treatment that can change the nature of CMS from hydrophobic to hydrophilic so that the impregnation process of amines becomes easier. Then the types of amines used for the impregnation process include monoethanolamine (MEA), 2-amino-2-methyl-1-propanol (AMP), and diethanolamine (DEA). The three types of amines were studied to determine their effect on breakthrough time so that the material with the best performance for $\mathrm{CO}_{2}$ separation was obtained.

\section{Materials and Methods}

\subsection{Materials}

The materials used in this study were palm kernel shell-based carbon molecular sieve (CMS) provided by PT Home System, Indonesia, hydrogen peroxide $\left(\mathrm{H}_{2} \mathrm{O}_{2}\right) 50 \%$ and monoethanolamine (MEA) 99.5\% supplied by Merck,2amino-2-methyl-1-propanol (AMP) 90\%, and diethanolamine (DEA) 98\% obtained from Sigma Aldrich. Then, the gases used for separation testing such as nitrogen $\left(\mathrm{N}_{2}\right)$ gas $100 \%$ and a gas mixture of methane $\left(\mathrm{CH}_{4}\right)$ $55 \%$ and carbon dioxide $\left(\mathrm{CO}_{2}\right) 45 \%$ which represents the composition of the biogas were imported from PT Samator Gas.

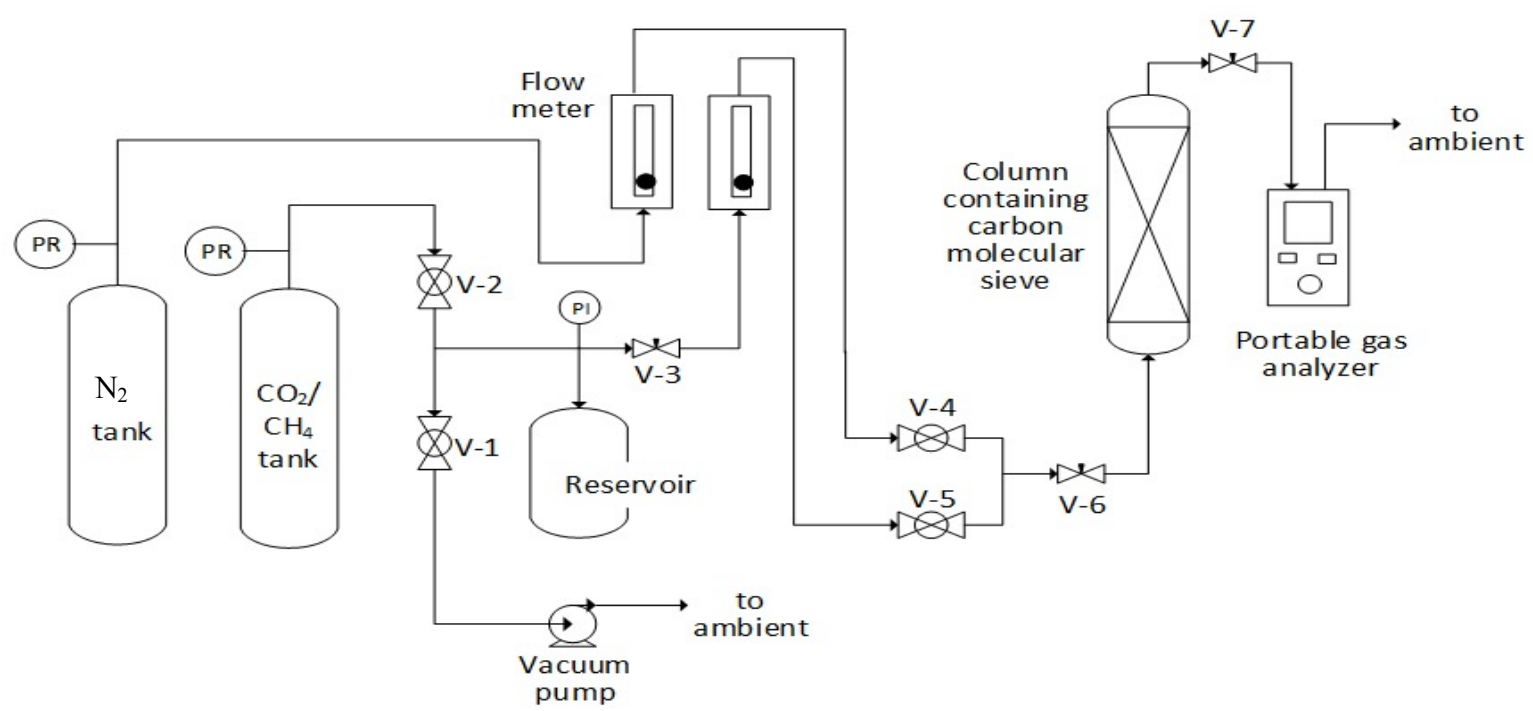

Fig. 1. Scheme of separation testing with a breakthrough system. The scheme taken from (Prasetyo et al., 2020). 


\subsection{Oxidation Process}

The CMS was crushed and sieved with a size of around 2025 mesh and then oxidized using a $10 \% \mathrm{H}_{2} \mathrm{O}_{2}$ solution. The oxidation process begins by diluting the $50 \% \mathrm{H}_{2} \mathrm{O}_{2}$ solution to $10 \%$. Oxidation was carried out in a three-neck flask by mixing 25 grams of CMS with $250 \mathrm{ml}$ of $10 \% \mathrm{H}_{2} \mathrm{O}_{2}$ solution at room temperature for $2 \mathrm{~h}$. After that, the oxidized carbon was separated with $\mathrm{H}_{2} \mathrm{O}_{2}$ solution and dried in an oven at $70{ }^{\circ} \mathrm{C}$ for $24 \mathrm{~h}$.

\subsection{Impregnation Process}

In this method, amines were mixed with the CMS with the help of a solvent. The solvent was then removed by evaporation. The impregnation process was prepared by mixing 25 grams of oxidized CMS, 1.3 grams of amines such as MEA, AMP, and DEA (5\% w/w) in the beaker, and adding distilled water until form slurry. The slurry was stirred using a magnetic stirrer at $300 \mathrm{rpm}$ for $1 \mathrm{~h}$ at room temperature. The mixture of CMS and amines was allowed to stand for $24 \mathrm{~h}$ at room temperature until the distilled water evaporated and then dried in an oven at $70^{\circ} \mathrm{C}$ for 24 $\mathrm{h}$. The materials impregnated were labeled as CMS-MEA, CMS-AMP, and CMS-DEA.

\subsection{Characterization}

Total surface area, pore-volume, and pore size of the CMS materials were characterized by the $\mathrm{N}_{2}$ sorption method using the NOVA 2000 analyzer (Quantachrome) at $77 \mathrm{~K}$. Identification of the functional groups in the wavenumber range $400-4000 \mathrm{~cm}^{-1}$ was carried out by Fourier transform infrared spectroscopy (FTIR) using 8201 PC FTIR, Shimadzu. Then, the morphology of the materials was characterized using scanning electron microscopy (SEM) with the JEOL JSM-6510LA instrument at a voltage of 15 $\mathrm{kV}$.

\subsection{Separation testing}

The separation process of $\mathrm{CO}_{2}$ and $\mathrm{CH}_{4}$ was carried out using a breakthrough system whose equipment scheme is shown in Fig.1. Inside the bed was filled with 14 grams of CMS material. CMS was first flushed by nitrogen gas with a flow rate of $200 \mathrm{ml} / \mathrm{min}$ until the gas detector showed no detected $\mathrm{CH}_{4}, \mathrm{CO}_{2}$, and $\mathrm{O}_{2}$ gas content. After that, the gas mixture of $\mathrm{CH}_{4}$ and $\mathrm{CO}_{2}$ flowed into the system with a flow rate of $100 \mathrm{ml} / \mathrm{min}$ at ambient temperature and pressure of 1.2 bar. The composition of methane and carbon dioxide was detected by a portable gas analyzer (Biogas Analyzer Gas board 3200plus, Hubei Cubic-Ruiyi Instrument Co. Ltd). The separation process was stopped when the concentrations of $\mathrm{CO}_{2}$ and $\mathrm{CH}_{4}$ gases detected by the portable gas analyzer were $35.5 \%$ and $54.5 \%$ respectively. After the separation process, CMS was flushed by passing nitrogen gas to the separator column at a flow rate of 200 $\mathrm{ml} / \mathrm{min}$.

Table 2

Physical properties from $\mathrm{N}_{2}$ sorption at $77 \mathrm{~K}$

\begin{tabular}{lccc} 
Materials & $\begin{array}{c}\text { Total surface } \\
\text { area }\left(\mathrm{m}^{2} / \mathrm{g}\right)\end{array}$ & $\begin{array}{c}\text { Total pore } \\
\text { volume } \\
\left(\mathrm{cm}^{3} / \mathrm{g}\right)\end{array}$ & $\begin{array}{c}\text { Average pore } \\
\text { size }(\mathrm{nm})\end{array}$ \\
\hline CMS & 708 & 0.33 & 1.87 \\
CMS-MEA & 164 & 0.10 & 2.40 \\
CMS-AMP & 228 & 0.14 & 2.39 \\
CMS-DEA & 211 & 0.13 & 2.40 \\
\hline
\end{tabular}
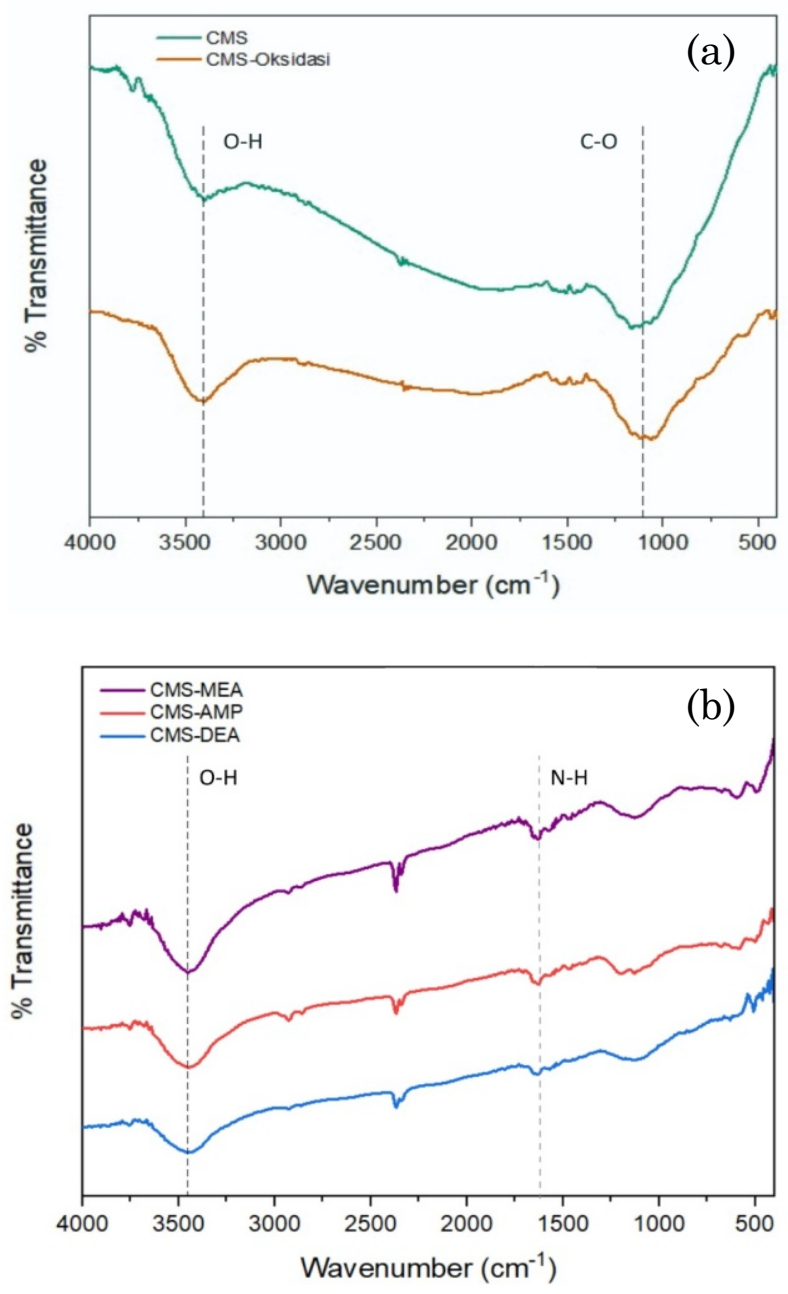

Fig. 2. FTIR spectra of the CMS and CMS-Oxidation (a), CMSMEA, CMS-AMP, and CMS-DEA (b)

\section{Results and Discussion}

\subsection{Characterization Results}

\subsection{1 $\mathrm{N}_{2}$ Sorption Analysis}

Table 2 shows the total surface area, pore-volume, and average pore size of the unmodified and modified CMSs. The results of the $\mathrm{N}_{2}$ sorption analysis showed that the modified CMS experienced a significant reduction in surface area and pore volume. The decrease in pores indicates that the impregnation process has been successful. The total surface area of the CMS is $708 \mathrm{~m}^{2} / \mathrm{g}$, after impregnation, the surface area drops to $164 \mathrm{~m}^{2} / \mathrm{g}$ (CMS-MEA), $228 \mathrm{~m}^{2} / \mathrm{g}$ (CMS-AMP), and $221 \mathrm{~m}^{2} / \mathrm{g}$ (CMSDEA). The total pore volume respectively decreases to 0.10 $\mathrm{cm}^{3} / \mathrm{g}$ (CMS-MEA), $0.14 \mathrm{~cm}^{3} / \mathrm{g}$ (CMS-AMP), and $0.13 \mathrm{~cm}^{3} / \mathrm{g}$ (CMS-DEA). This decrease is caused by amine groups that have filled the pores of the carbon and blocked most of the pore structures. Although they clog pores, amines provide an active site that can increase the interaction between $\mathrm{CO}_{2}$ and carbon. The specific surface area and pore volume are considered very important parameters during physisorption. However, in this study, the pores have a role to increase the number of amines that enter the carbon through the impregnation process. 


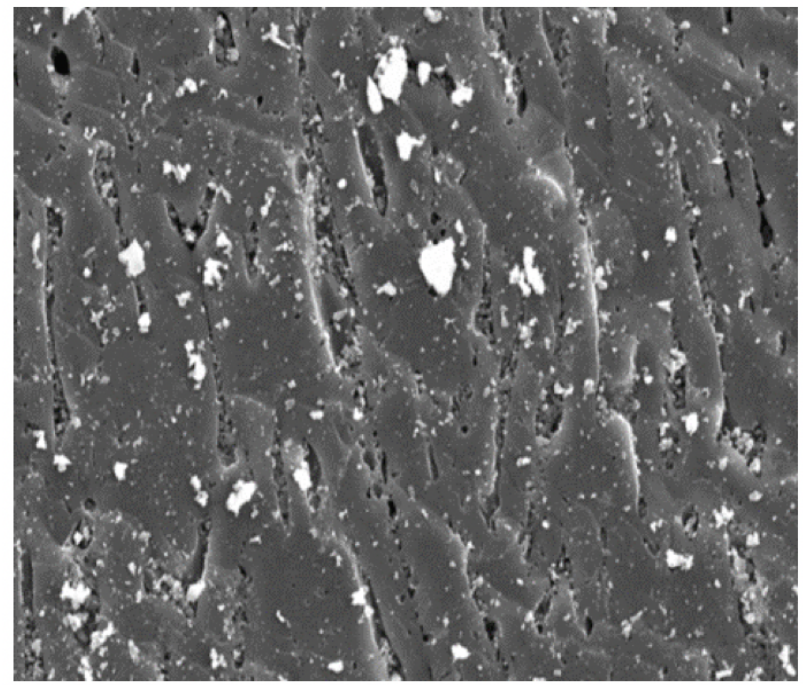

(a)

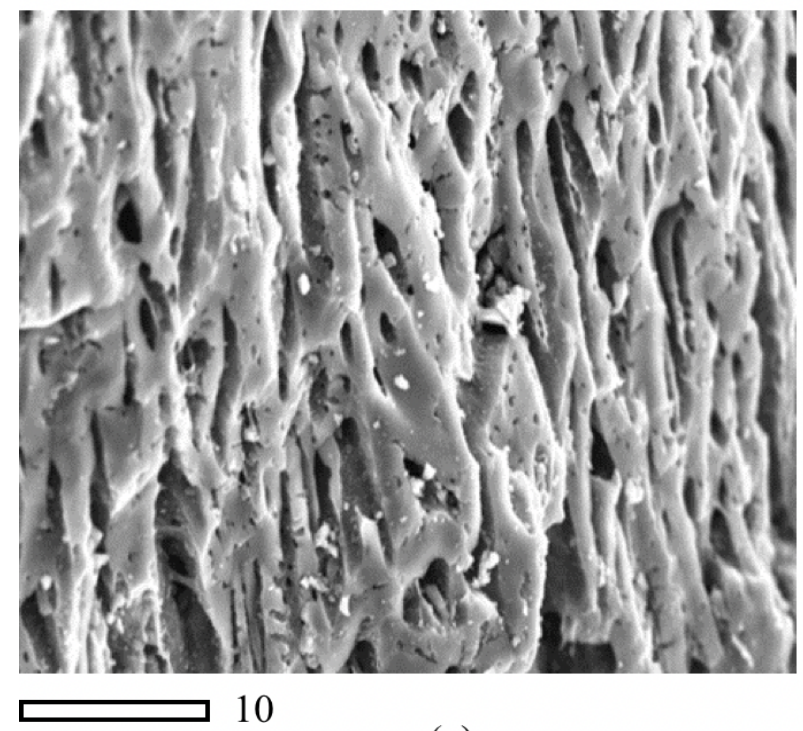

(c)

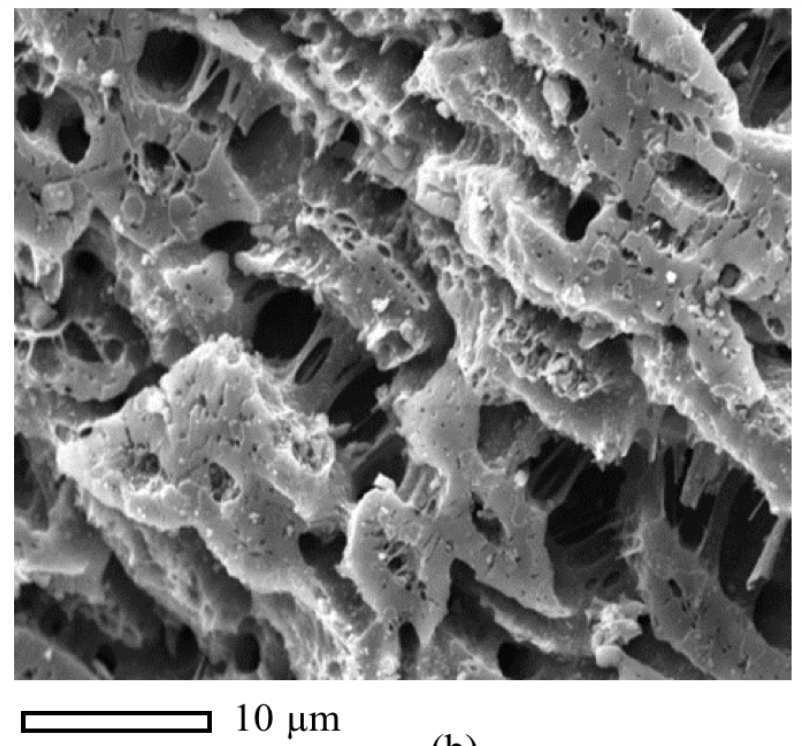

(b)

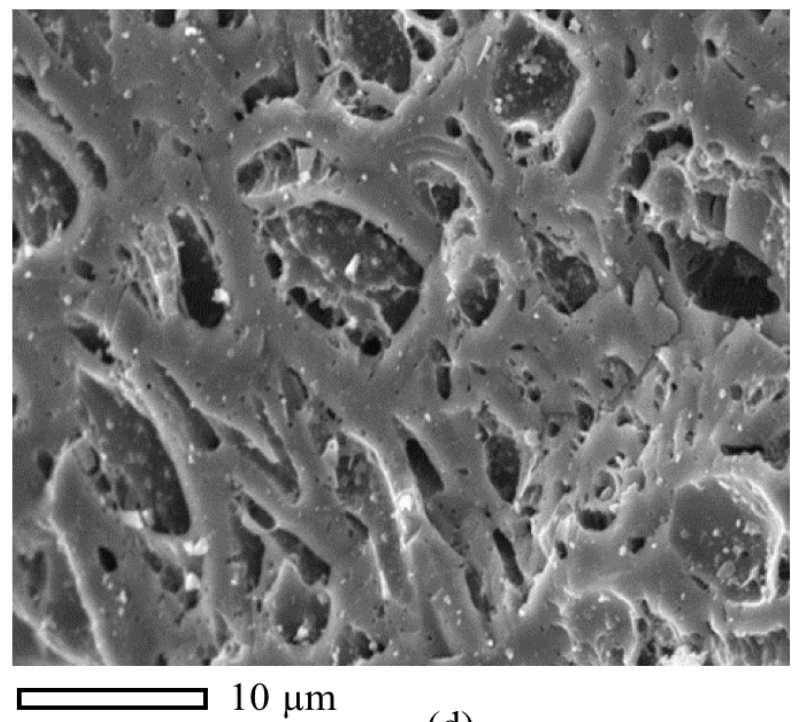

(d)

Fig. 3. SEM image of (a) CMS, (b) CMS-MEA, (c) CMS-AMP, and (d) CMS-DEA magnified 1.000 time

\subsubsection{Fourier Transform Infrared Spectroscopy (FTIR)}

Fig. 2(a) shows the FTIR spectrum of unmodified CMS and oxidized CMS using hydrogen peroxide. A strong peak at $3400 \mathrm{~cm}^{-1}$ indicates $\mathrm{O}-\mathrm{H}$ stretching, while the strong spectra at $1085 \mathrm{~cm}^{-1}$ show the presence of $\mathrm{C}-\mathrm{O}$ stretching of alcohol groups. In the FTIR spectra, it was shown that oxidized CMS had a sharper peak. This indicates that oxidation using hydrogen peroxide produces an $\mathrm{OH}$ group. The pre-oxidation helps to increase the $\mathrm{N}$ loading during the impregnation process, due to the presence of the $\mathrm{O}$ functional on the surface plays an important role in determining the amount of $\mathrm{N}$ loading to the carbon surface.

FTIR spectrum of the amine impregnated CMS is shown in Fig. 2(b) the success of the amine impregnation process into the carbon structure can be seen from the presence of the $\mathrm{N}-\mathrm{H}$ bending vibration of amines groups at the spectra of 1655-1641 $\mathrm{cm}^{-1}$ (Kongnoo et al., 2016). In this study, FTIR results on CMS-MEA, CMS-AMP, and CMSDEA materials showed that the N-H bending was indicated at the peaks of $1650 \mathrm{~cm}^{-1}$. In addition, it is seen that the C$\mathrm{O}$ stretching peak of the carbon-bound alcohol group is not as sharp as in Fig. 2(a), due to the C-O has reacted with an amine. The wavenumber $3400 \mathrm{~cm}^{-1}$ associated with the $\mathrm{N}$ $\mathrm{H}$ stretching where shows that CMS-MEA has a sharper peak than other materials. This allows that the loading amount of amines is greater.

\subsubsection{Scanning Electron Microscopy (SEM)}

SEM analysis results showed a significant difference in morphological structure between carbon without impregnation and carbon loaded with amines. The carbon 
surface before impregnation is presented in Fig. 3(a), while the carbon surface after impregnation with amines is presented in Figs. 3(b-d). Fig. 3(a) shows that carbon without impregnation has a denser morphology. Meanwhile, the amine impregnated carbon has a more hollow morphology as shown in Figs. 3(b), 3(c), and 3(d). CMS-MEA shows a large cavity compared to CMS-AMP and CMS-DEA. SEM images only show the surface morphology of the carbon, not showing a micro or mesosized pore.

\subsection{Breakthrough time result}

The breakthrough time was studied to measure the performance of $\mathrm{CO}_{2}$ and $\mathrm{CH}_{4}$ gas separation. Fig. 4(a) shows the breakthrough curves of $\mathrm{CO}_{2}$, while the breakthrough curve of $\mathrm{CH}_{4}$ can be seen in Fig. 4(b). In the beginning, $\mathrm{CH}_{4}$ and $\mathrm{CO}_{2}$ gas detected by the portable gas analyzer showed the same concentration of $0 \%$. However, the difference in the diffusion rate of gas molecules causes the $\mathrm{CH}_{4}$ molecule to pass through the pores faster than the $\mathrm{CO}_{2}$ molecule which allows the two gases to separate. The diffusivity of $\mathrm{CH}_{4}$ and $\mathrm{CO}_{2}$ was $1 \times 10^{-10} \mathrm{~m}^{2} / \mathrm{s}$ and $1 \times 10^{-11} \mathrm{~m}^{2} / \mathrm{s}$ respectively (Prasetyo et al., 2020). In addition, carbon is more selective towards $\mathrm{CO}_{2}$ than $\mathrm{CH}_{4}$ because of its higher affinity for carbon. Due to the diffusion rate of the $\mathrm{CO}_{2}$ molecule is slower, it allows this molecule to be trapped on the carbon. The $\mathrm{CO}_{2}$ gas started to breakthrough out from the carbon when carbon is in the saturation stage. Thus, the $\mathrm{CO}_{2}$ concentration displayed increases to its initial concentration and the methane gas concentration decreases again.

Modification of CMS by impregnated amine is the method mostly used to enhance the interaction between the carbon surface and acid molecules, such as $\mathrm{CO}_{2}, \mathrm{H}_{2} \mathrm{~S}$, and $\mathrm{SO}_{2}$ (Sevilla et al., 2012). The results showed that CMSMEA, CMS-AMP, and CMS-DEA take a longer time to reach saturation point compared to non-impregnated CMS. The amine group provides the active site on the carbon surface which can increase the capture of $\mathrm{CO}_{2}$ molecules due to the chemisorption effect. The active site from the $\mathrm{N}$ functional group will cause increasing the polarity and basicity properties of the carbon surface (Sevilla et al., 2012). The interaction between $\mathrm{CO}_{2}$ and amines occurs based on the Lewis acid-base principle. Amine acts as Lewis's base inducing electron-donor, while $\mathrm{CO}_{2}$ acts as an electron-accepting Lewis acid. its properties provide a high affinity for a stronger interaction between $\mathrm{CO}_{2}$ and carbon (Chiang \& Juang, 2017).

On the breakthrough curve seen that CMS-DEA is the first to reach the saturation point of the three types of amines. It may be related to DEA which is a group of secondary amines and has a larger molecular weight (105 $\mathrm{g} / \mathrm{mol}$ ). Secondary amines were less reactive than primary amines (Zelenak et al., 2008). MEA and AMP were included as primary amines. However, for the same amine groups, the structure of the smaller amine and have fewer branches will provide more active sites (Khalil et al., 2012). AMP has a larger molecular weight $(89 \mathrm{~g} / \mathrm{mol})$ and more branched which makes it difficult for the amines molecule to occupy the pores. Therefore, this experiment shows that CMSMEA has a longer breakthrough time than CMS-AMP and CMS-DEA.

The $\mathrm{CO}_{2}$ sorption capacity can be determined when $\mathrm{CO}_{2}$ first interacts with carbon until the $\mathrm{CO} 2$ molecules started to breakthrough out from the column. The uptake capacity of $\mathrm{CO}_{2}$ for impregnated and non-impregnated CMS is presented in Table 3. Based on Table 3 the loading of amines on carbon shows a better $\mathrm{CO}_{2}$ sorption performance. The sorption capacity of $\mathrm{CO}_{2}$ increased to 13.2 $\mathrm{mg} / \mathrm{g}$ for CMS-MEA, $11.8 \mathrm{mg} / \mathrm{g}$ for CMS-AMP, and $9.9 \mathrm{mg} / \mathrm{g}$ for CMS-DEA, respectively. Thus, the active site on the carbon surface has stronger properties so that in this study the process is more likely to be chemisorption. In previous studies, CMS impregnated with ammonium hydroxide had increased $\mathrm{CO}_{2}$ sorption capacity by $24 \%$ (1.61 $\mathrm{mmol} / \mathrm{g}$ to 2.0 $\mathrm{mmol} / \mathrm{g}$ at $298 \mathrm{~K}$ ) as an effect of the introduced nitrogen function (Bai et al., 2013). Other materials such as fly ash carbon-impregnated by MEA can increase the $\mathrm{CO}_{2}$ uptake up to $64 \%$ ( $41.8 \mathrm{mg} / \mathrm{g}$ to $68.6 \mathrm{mg} / \mathrm{g}$ at $30^{\circ} \mathrm{C}$ ) (Mercedes Maroto-Valer et al., 2008).
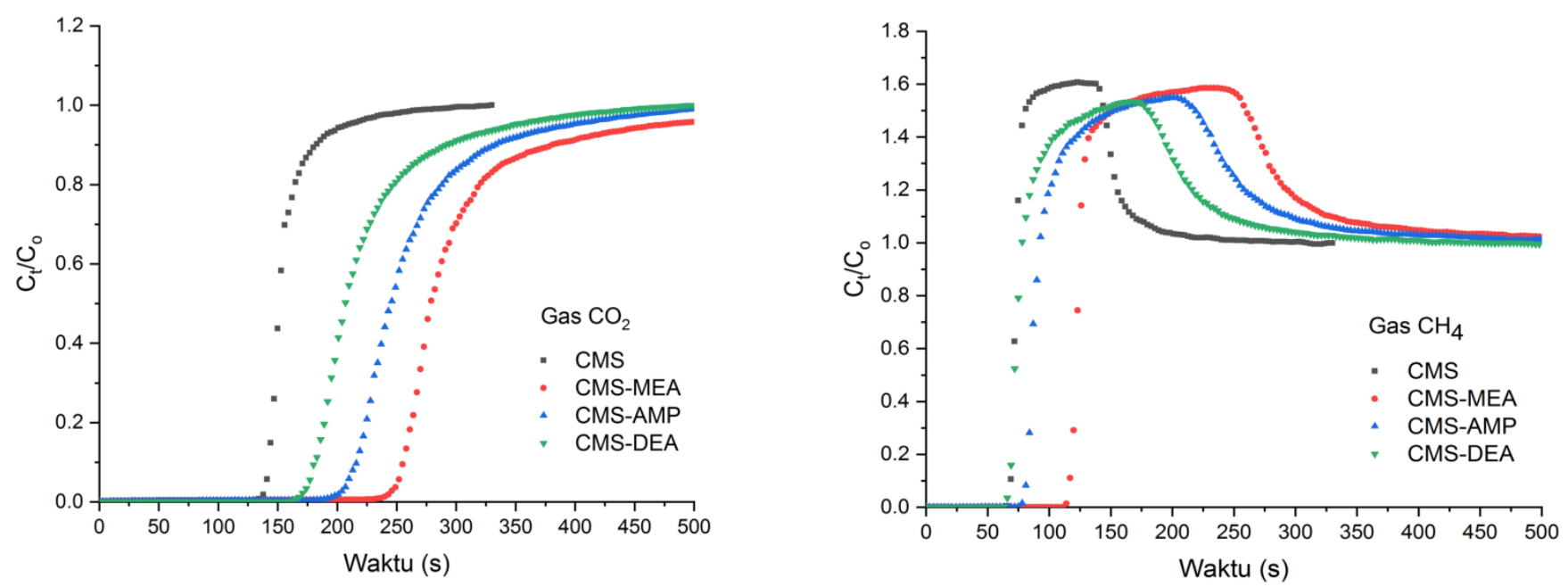

Fig. 4 Breakthrough curve of a) $\mathrm{CO}_{2}$ and (b) $\mathrm{CH}_{4}$ 
Table 3

Uptake capacity of $\mathrm{CO}_{2}$

\begin{tabular}{lcc} 
Materials & $\begin{array}{c}\mathbf{C O}_{2} \text { uptake } \\
\text { (mg/g) }\end{array}$ & $\begin{array}{c}\text { Enhancement } \\
(\%)\end{array}$ \\
\hline CMS & 7.9 & - \\
CMS-MEA & 13.2 & 67 \\
CMS-AMP & 11.8 & 49 \\
CMS-DEA & 9.9 & 25 \\
\hline
\end{tabular}

\section{Conclusion}

CMS was prepared by modification of palm kernel shellderived porous carbon using amine groups that have the potential for biogas purification. The introduction of amine groups into the carbon structure causes the pore structure to become clogged so that the surface area is reduced as shown in the BET results. However, impregnation of carbon with base groups has increased the chemical surface for carbon capture. The presence of $\mathrm{N}$ functional groups can increase the acid-base interaction between $\mathrm{CO}_{2}$ and the carbon surface due to the chemisorption effect. The oxidation treatment before the impregnation process gives the functional group $\mathrm{O}$ on the carbon surface as seen in the FTIR results, where the $\mathrm{O}$ functional group has an important role in increasing the $\mathrm{N}$ loading on the carbon. Loading of amines on CMS showed better breakthrough separation performance compared to CMS without amine impregnated. CMS impregnated with MEA showed a longer breakthrough time and higher $\mathrm{CO}_{2}$ sorption capacity.

\section{Acknowledgments}

This study was supported by Indonesian Fund Management Agency for Oil Palm Estate (BPDP-KS, Grant No. PRJ-65/DPKS/2018).

\section{References}

Ahmad, M. A., Wan Daud, W. M. A., \& Aroua, M. K. (2008). Adsorption kinetics of various gases in carbon molecular sieves (CMS) produced from palm shell. Colloids and Surfaces A: Physicochemical and Engineering Aspects, 312(2-3), https://doi.org/10.1016/j.colsurfa.2007.06.040

$131-135$.

Akkarawatkhoosith, N., Kaewchada, A., \& Jaree, A. (2019). Highthroughput CO 2 capture for biogas purification using monoethanolamine in a microtube contactor. Journal of the Taiwan Institute of Chemical Engineers, 98, 113-123. https://doi.org/10.1016/j.jtice.2018.05.002

Alcañiz-Monge, J., Marco-Lozar, J. P., \& Lillo-Ródenas, M. Á. (2011). $\mathrm{CO}_{2}$ separation by carbon molecular sieve monoliths prepared from nitrated coal tar pitch. Fuel Processing Technology, 92(5), $915-919$. https://doi.org/10.1016/j.fuproc.2010.12.010

Appels, L., Baeyens, J., Degrève, J., \& Dewil, R. (2008). Principles and potential of the anaerobic digestion of waste-activated sludge. Progress in Energy and Combustion Science, 34(6), 755-781. https://doi.org/10.1016/j.pecs.2008.06.002

Ariyanto, T., Cahyono, R. B., Vente, A., Mattheij, S., Millati, R., Sarto, Taherzadeh, M. J., \& Syamsiah, S. (2017). Utilization of fruit waste as biogas plant feed and its superiority compared to landfill. International Journal of Technology, 8(8), 1385-1392. https://doi.org/10.14716/ijtech.v8i8.739

Bai, B. C., Cho, S., Yu, H. R., Yi, K. B., Kim, K. D., \& Lee, Y. S
(2013). Effects of aminated carbon molecular sieves on breakthrough curve behavior in $\mathrm{CO}_{2} / \mathrm{CH}_{4}$ separation. Journal of Industrial and Engineering Chemistry, 19(3), 776-783. https://doi.org/10.1016/j.jiec.2012.10.016

Chiang, Y. C., \& Juang, R. S. (2017). Surface modifications of carbonaceous materials for carbon dioxide adsorption: A review. Journal of the Taiwan Institute of Chemical Engineers, 71 , 214-234. https://doi.org/10.1016/j.jtice.2016.12.014

Cho, S., Lee, D., \& Lee, Y. S. (2015). Separation of biomass using carbon molecular sieves treated with hydrogen peroxide. Journal of Industrial and Engineering Chemistry, 21, 278282. https://doi.org/10.1016/j.jiec.2013.12.113

Das, D., \& Meikap, B. C. (2020). Role of amine-impregnated activated carbon in carbon dioxide capture. Indian Chemical Engineer, O(0), 1-13. https://doi.org/10.1080/00194506.2020.1760150

Hosseini, S. E., \& Wahid, M. A. (2014). Development of biogas combustion in combined heat and power generation. Renewable and Sustainable Energy Reviews, 40, 868-875. https://doi.org/10.1016/j.rser.2014.07.204

Khalil, S. H., Aroua, M. K., \& Daud, W. M. A. W. (2012). Study on the improvement of the capacity of amine-impregnated commercial activated carbon beds for Co 2 adsorbing. Chemical Engineering Journal, 183(2012), 15-20. https://doi.org/10.1016/j.cej.2011.12.011

Kongnoo, A., Intharapat, P., Worathanakul, P., \& Phalakornkule, C. (2016). Diethanolamine impregnated palm shell activated carbon for $\mathrm{CO}_{2}$ adsorption at elevated temperatures. Journal of Environmental Chemical Engineering, 4(1), 73-81. https://doi.org/10.1016/j.jece.2015.11.015

Lee, C. S., Ong, Y. L., Aroua, M. K., \& Daud, W. M. A. W. (2013). Impregnation of palm shell-based activated carbon with sterically hindered amines for $\mathrm{CO}_{2}$ adsorption. Chemical Engineering Journal, 219, 558-564. https://doi.org/10.1016/j.cej.2012.10.064

Mercedes Maroto-Valer, M., Lu, Z., Zhang, Y., \& Tang, Z. (2008). Sorbents for $\mathrm{CO}_{2}$ capture from high carbon fly ashes. Waste Management, 28(11), 2320-2328. https://doi.org/10.1016/j.wasman.2007.10.012

Mohamed, A. R., Mohammadi, M., \& Darzi, G. N. (2010). Preparation of carbon molecular sieve from lignocellulosic biomass: A review. Renewable and Sustainable Energy Reviews, 14(6), 1591-1599. https://doi.org/10.1016/j.rser.2010.01.024

Mursec, B., Vindis, P., Janzekovic, M., Brus, M., \& Cus, F. (2009). Analysis of different substrates for processing into biogas Manufacturing and processing. Journal of Achievements in Materials and Manufacturing Engineering, 37(2), 652-659.

Poletti, A., D’Alessandro, E., Poletti, L., Poletti, R., \& Arca, S. (2011). Upgrading ff Biogas Technology Through The Application of Gas Hydrates.Icgh.

Prasetyo, I., Mukti, N. I. F., Cahyono, R. B., Prasetya, A., \& Ariyanto, T. (2020). Nanoporous Carbon Prepared from Palm Kernel Shell for $\mathrm{CO}_{2} / \mathrm{CH}_{4}$ Separation. Waste and Biomass Valorization, 0123456789. https://doi.org/10.1007/s12649-020-01006-4

Prasetyo, I., Rochmadi, Wahyono, E., \& Ariyanto, T. (2017). Controlling synthesis of polymer-derived carbon molecular sieve and its performance for $\mathrm{CO}_{2} / \mathrm{CH}_{4}$ separation. Engineering Journal, 21(4), 83-94. https://doi.org/10.4186/ej.2017.21.4.83

Rashidi, N. A., \& Yusup, S. (2017). Potential of palm kernel shell as activated carbon precursors through single stage activation technique for carbon dioxide adsorption. Journal of Cleaner Production, 168, 474-486. https://doi.org/10.1016/j.jclepro.2017.09.045

Rasi, S., Läntelä, J., \& Rintala, J. (2011). Trace compounds affecting biogas energy utilisation - A review. Energy Conversion and Management, 52(12), 3369-3375. https://doi.org/10.1016/j.enconman.2011.07.005

Ricaurte, M., Dicharry, C., Broseta, D., Renaud, X., \& Philippe 
Torre, J. (2012). CO2 Removal from a $\mathrm{CO}_{2}-\mathrm{CH}_{4}$ Gas Mixture by Clathrate Hydrate.pdf.

Sevilla, M., Falco, C., Titirici, M. M., \& Fuertes, A. B. (2012). Highperformance $\mathrm{CO}_{2}$ sorbents from algae. RSC Advances, 2(33), 12792-12797. https://doi.org/10.1039/c2ra22552b

Silvestre-Albero, A. M., Wahby, A., Silvestre-Albero, J., RodríguezReinoso, F., \& Betz, W. (2009). Carbon molecular sieves prepared from polymeric precursors: Porous structure and hydrogen adsorption properties. Industrial and Engineering Chemistry Research, 48(15), 7125-7131. https://doi.org/10.1021/ie900091n

Song, X., Wang, L., Ma, X., \& Zeng, Y. (2017). Adsorption equilibrium and thermodynamics of $\mathrm{CO}_{2}$ and $\mathrm{CH}_{4}$ on carbon molecular sieves. Applied Surface Science, 396, 870-878. https://doi.org/10.1016/j.apsusc.2016.11.050

Surendra, K. C., Takara, D., Hashimoto, A. G., \& Khanal, S. K. (2014). Biogas as a sustainable energy source for developing countries: Opportunities and challenges. Renewable and
Sustainable Energy Reviews, 31, 846-859. https://doi.org/10.1016/j.rser.2013.12.015

Tae-Hwan, K., Vijayalakshmi, S., Jin, S. S., \& Dong, K. J. (2003). Carbon molecular sieves (CMS) from coconut shell by carbonization and carbon dioxide activation. Indian Journal of Chemical Technology, 10(3), 298-304.

Wahby, A., Silvestre-Albero, J., Sepúlveda-Escribano, A., \& Rodríguez-Reinoso, F. (2012). $\mathrm{CO}_{2}$ adsorption on carbon molecular sieves. Microporous and Mesoporous Materials, 164 , 280-287. https://doi.org/10.1016/j.micromeso.2012.06.034

Zelenak, V., Halamova, D., Gaberova, L., Bloch, E., \& Llewellyn, P. (2008). Amine-modified SBA-12 mesoporous silica for carbon dioxide capture: Effect of amine basicity on sorption properties. Microporous and Mesoporous Materials, 116(13), 358-364. https://doi.org/10.1016/j.micromeso.2008.04.023 